\title{
Signal Transduction of Eel Luteinizing Hormone Receptor (eelLHR) and Follicle Stimulating Hormone Receptor (eelFSHR) by Recombinant Equine Chorionic Gonadotropin (rec-eCG) and Native eCG
}

\author{
Munkhzaya Byambaragchaa ${ }^{1}$, So-Yun Lee ${ }^{1}$, Dae-Jung Kim², \\ Myung-Hwa Kang ${ }^{3}$, and †Kwan-Sik Min ${ }^{1}$ \\ ${ }^{1}$ Animal Biotechnology, Graduate School of Future Convergence Technology, Dept. of Animal Life Science, \\ Institute of Genetic Engineering, Hankyong National University, Ansung 17579, Korea \\ ${ }^{2}$ Aquaculture Research Division, National Institute of Fisher Science (NIFS), Busan 46083, Korea \\ ${ }^{3}$ Dept. of Food Science and Nutrition, Hoseo University, Asan 31499, Korea
}

\begin{abstract}
Previous studies showed that recombinant equine chorionic gonadotropin (rec-eCG $\beta / \alpha$ ) exhibits both folliclestimulating hormone (FSH) and luteinizing hormone (LH)-like activities in rat LHR- and FSHR-expressing cells. In this study, we analyzed signal transduction by eelFSHR and eelLHR upon stimulation with rec-eCG $\beta / \alpha$ and native eCG. The cyclic adenosine monophosphate (cAMP) stimulation in CHO-K1 cells expressing eelLHR was determined upon exposure to different doses $(0-1,450 \mathrm{ng} / \mathrm{mL})$ of rec-eCG $\beta / \alpha$ and native eCG. The $\mathrm{EC}_{50}$ values of rec-eCG $\beta / \alpha$ and native eCG were 172.4 and $786.6 \mathrm{ng} / \mathrm{mL}$, respectively. The activity of rec-eCG $\beta / \alpha$ was higher than that of native eCG. However, signal transduction in the CHO PathHunter Parental cells expressing eelFSHR was not enhanced by stimulation with both agonist rec-eCG $\beta / \alpha$ and native eCG. We concluded that rec-eCG $\beta / \alpha$ and native eCG were completely active in cells expressing eelLHR, similar to the activity in the mammalian cells expressing LHRs. However, rec-eCG $\beta / \alpha$ and native eCG did not invoke any signaling response in the cells expressing eelFSHR. These results suggest that eCG has a potent activity in cells expressing eelLHR. Thus, we also suggest that rec-eCG $\beta / \alpha$ can induce eel maturation by administering gonadotropic reagents (LH), such as salmon pituitary extract.
\end{abstract}

Key words : rec-eCG $\beta / \alpha$, Native eCG, eelFSHR, eelLHR, cAMP stimulation

\section{INTRODUCTION}

Equine chorionic gonadotropin (eCG) is a unique member of the gonadotropin family, as it can perform both luteinizing hormone (LH)- and follicle-stimulating hormone (FSH)-like activity in non-equid species as well (Chopineau et al., 2001). Members of the glycoprotein family, including $\mathrm{CG}$, LH, FSH, and thyroid-stimulating hormone
(TSH), comprise two non-covalently linked $\alpha$ - and $\beta$ subunits (Min et al., 2004; Park et al., 2010, 2017; Lee et al., 2017). The $\beta$-subunits of eCG and eLH have identical primary structures (Min et al., 1996). Thus, eCG could be an ideal model for studying the structure/function associations of gonadotropins, as it exhibits the properties of both, its pituitary and placental, counterparts (Galet et al., 2009; Park et al., 2017).

Manuscript received January 31, 2018, Received in revised form March 15, 2018, Accepted March 17, 2018

${ }^{\dagger}$ Corresponding Author : Kwan-Sik Min, Animal Biotechnology, Graduate School of Future Convergence Technology, Dept. of Animal Life Science, Institute of Genetic Engineering, Hankyong National University, Ansung 17579, Korea. Tel: +82-31-670-5421, Fax: +82-31-670-5417, E-mail: ksmin@hknu.ac.kr

This is an Open Access article distributed under the terms of the Creative Commons Attribution Non-Commercial License (http:// creative-commons.org/licenses/by-nc/3.0) which permits unrestricted non-commercial use, distribution, and reproduction in any medium, provided the original work is properly cited. 
In our previous study, we produced recombinant eCG (rec-eCG) mutant proteins from $\mathrm{CHO}-\mathrm{K} 1$ cells, which exhibited dual LH- and FSH-like activity in rat Leydig and granulosa cells (Min et al., 1996, 2004) and in cells expressing ratLH/CGR (rLH/CGR) and rFSHR (Park et al., 2010; Jeoung et al., 2010; Lee et al., 2017) and internalized rLH/CGR and rFSHR (Park et al., 2017).

Japanese eel is one of the most important fish species being aquacultured in East Asian countries, including Japan and Korea (Kagawa et al., 1998). Eel gonadal development can be induced by administering gonadotropin reagents, such as the salmon pituitary extract (Kim et al., 2016a; Kazeto et al., 2008; Kobayashi et al., 2010). rec-eel FSH and LH have recently been widely reported to be involved in reproductive endocrinology (Kobayashi et al., 2010; Kazeto et al., 2008; Ohta et al., 2007). We also recently analyzed the biological activities of the specific monoclonal antibodies for rec-eelFSH $\beta / \alpha$ and the receelLH $\beta / \alpha$ produced from $\mathrm{CHO}$ cells by measuring the percentage of germinal vesicle breakdown in vitro (Kim et al., 2016a,b). A large quantity of high-quality milt was transported, 18-24 $\mathrm{h}$ after injection, from the testes to the sperm duct for storage when treated with rec-eelLH $(500 \mu \mathrm{g} / \mathrm{kg}$ BW) (Ohta et al., 2017).

In the present study, we constructed a mammalian expression vector containing eelLHR and eelFSHR. The expression vectors were transfected into $\mathrm{CHO}-\mathrm{K} 1$ cells and PathHunter CHO-K1 Parental cells; we then assessed the signal transduction activity of eelLHR and eelFSHR upon exposure to rec-eCG $\beta / \alpha$ and native eCG.

\section{MATERIALS AND METHODS}

\section{Materials}

The expression vector, pcDNA3, was purchased from Invitrogen (San Diego, CA, USA). CHO-K1 cells were obtained from the Japanese Cancer Research Resources Bank (Tokyo, Japan). Endonucleases were purchased from Boehrin- ger Mannheim (MA, USA) and Takara (Osaka, Japan). Polymerase chain reaction (PCR) reagents were from Takara (Japan). Ham's F-12, CHO-S-SFM II, Geneticin, Lipofectamine 2000, and fetal bovine serum (FBS) were obtained from Gibco BRL (MD, USA). The QIAprep-Spin plasmid kit was purchased from QIAGEN Inc. (Hilden, Germany). FreeStyle MAX reagent, FreeStyle CHO expression medium, pCMV-ARMS1-PK2 expression vector, anti-myc antibody, antibiotics, and assay complete medium were purchased from Invitrogen, the PathHunter CHO-K1 $\beta$-arrestin Parental cell line was obtained from DiscoveRx (San Diego, CA, USA) and disposable spinner flasks were from Corning Incorporated (NY, USA). PMSG ELISA kit was obtained from DRG International Inc. (Mountainside, NJ). The cAMP Dynamic 2 immunoassay kit was from Cisbio Bioassay (France).

The oligonucleotides were synthesized by Green Gene Bio (Seoul, Korea). Fetal bovine serum was from Hyclone laboratories (Utah, USA). Centriplus Centrifugal Filter Devices were purchased from Amicon Bio separations (MA, USA). All other reagents used were from SigmaAldrich (USA) and Wako Pure Chemicals (Osaka, Japan).

\section{Construction of the tethered eCG $\beta / \alpha$}

cDNA encoding the tethered eCG $\beta / \alpha$ was inserted in the pcDNA3 mammalian expression vector, as previously reported (Min et al., 2004). The epitope, myc-tag (Glu-GlnLys-Leu-Ile-Ser-Glu- Glu-Asp-Leu) was inserted into the tethered eCG $\beta / \alpha$ between the first and second amino acids in the $\beta$-subunit of the mature protein (Min et al., 2004). The schematic diagrams of rec-eCG $\beta / \alpha$ production are shown in a previous publication (Lee et al., 2017) (Fig. 1). These fragments were digested with EcoR I and Sal I and ligated into the eukaryotic expression vector, pcDNA3. The plasmids were then purified and sequenced in both directions by automated DNA sequencing to ensure that the correct mutations had been introduced (designated as pcDNA3-eCG $\beta / \alpha)$. 


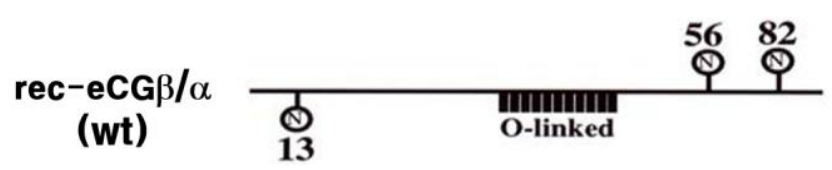

Fig. 1. Schematic diagram of rec-eCG $\beta / \boldsymbol{\alpha}$. The tethered eCG cDNA was ligated into the pcDNA3 mammalian expressing vector by $E c o$ RI and SalI sites. receCG, recombinant equine chorionic gonadotropin; eCG, equine chorionic gonadotropin; cDNA, complementary DNA.

\section{Production of tethered rec-eCG $\beta / \alpha$ proteins in $\mathrm{CHO}$ suspension cells}

The rec-eCG $\beta / \alpha$ proteins were expressed, as described previously (Lee et al., 2017), by transfecting the expression vector into CHO-S cells using the FreeSytle MAX reagent transfection method according to the supplier's instructions. Briefly, CHO-S cells were cultured with Free Style $\mathrm{CHO}$ expression medium at a density of $1 \times 10^{7}$ cells/ $30 \mathrm{~mL}$ for 3 days. One day prior to transfection, the cells were passaged at $5-6 \times 10^{5}$ cells $/ \mathrm{mL}$ with $\mathrm{CHO}$ expression medium in $125 \mathrm{~mL}$ disposable spinner flasks. On the day of transfection, the cell density was about $1.2-1.5 \times 10^{6}$ cells $/ \mathrm{mL}$. Next, DNA $(160 \mu \mathrm{g})$ was mixed gently in $1.2 \mathrm{~mL}$ of OptiPRO serum-free medium (SFM), and FreeStyle MAX reagent $(160 \mu \mathrm{L})$ was also mixed gently in $1.2 \mathrm{~mL}$ of OptiPRO SFM. Both of the medium mixtures were incubated for 5 minutes at room temperature (RT). The solutions were then mixed, and the complex $(2.4 \mathrm{~mL})$ was added to each cell suspension flask. For the rec-protein assay, the culture medium was collected on day 7 . Finally, the culture media were collected on day 7 after transfection and centrifuged at $15,000 \mathrm{rpm}$ at $4^{\circ} \mathrm{C}$ for $10 \mathrm{~min}$ to remove cell debris.

The supernatant was collected and concentrated by freeze-drying in an Amicon Stirred cell concentrator and stored at $-20^{\circ} \mathrm{C}$ until the assays were performed. Recombinant proteins were analyzed by enzyme-linked immunosorbent assay (ELISA), as previously reported (Lee et al., 2017).

\section{Quantification of rec-eCGß/a proteins}

The tethered rec-eCG proteins were produced in the $\mathrm{CHO}$ suspension cells and rec-eCG was quantified using the PMSG ELISA kit, according to the supplier's protocol (DRG, USA).

\section{Transient transfection of eelLHR in CHO-K1 cells} and stable transfection of eelFSHR in PathHunter CHO-K1 EA-Parental cells

The method for the construction of cDNAs encoding the eelLHR and eelFSHR was modified as previously reported (Kim et al., 2016a). The PCR fragments were ligated into the pcDNA3 (EcoRI-XhoI site) mammalian expressing vectors (Fig. 2). Transfection of CHO-K1 cells was performed using the liposome transfection method, as previously described (Lee et al., 2017). CHO cells were cultured in growth medium [Ham's F-12 media containing penicillin $(50 \mathrm{U} / \mathrm{mL})$, streptomycin $(50 \mu \mathrm{g} / \mathrm{mL})$, glutamine (2 $\mathrm{mM}$ ), and $10 \%$ fetal bovine serum]. $\mathrm{CHO}$ cells were grown at $80-90 \%$ confluence in $6-$ well plates. After combining the diluted DNA with Lipofectamine reagent, the mixture was incubated for $20 \mathrm{~min}$. $\mathrm{CHO}$ cells were washed with Opti-MEM and the DNA-Lipofectamine complex was added to each well. After $5 \mathrm{~h}, \mathrm{CHO}$ growth medium including 20\% FBS was added to each well. Fresh growth medium was added at $24 \mathrm{~h}$ after transfection. The cells were then subjected to cAMP analysis, 48-72 $\mathrm{h}$ after transfection.

PathHunter CHO-K1 EA-Parental cells, which are engineered to stably express the enzyme acceptor-tagged $\beta$ arrestin fusion protein, were transiently and stably transfected according to the supplier's protocol. The PCR fragments were ligated into the pCMV-ARMS1-PK2 (Nhe1SacI site) mammalian expressing vectors (Fig. 2). PathHunter CHO-K1 EA-Parental cells were cultured in AssayComplete $\mathrm{CHO}-\mathrm{K} 1$ culture medium [AssayComplete CHO-K1 medium containing 10\% fetal bovine serum and antibiotics (penicillin, streptomycin, and glutamine)]. For 

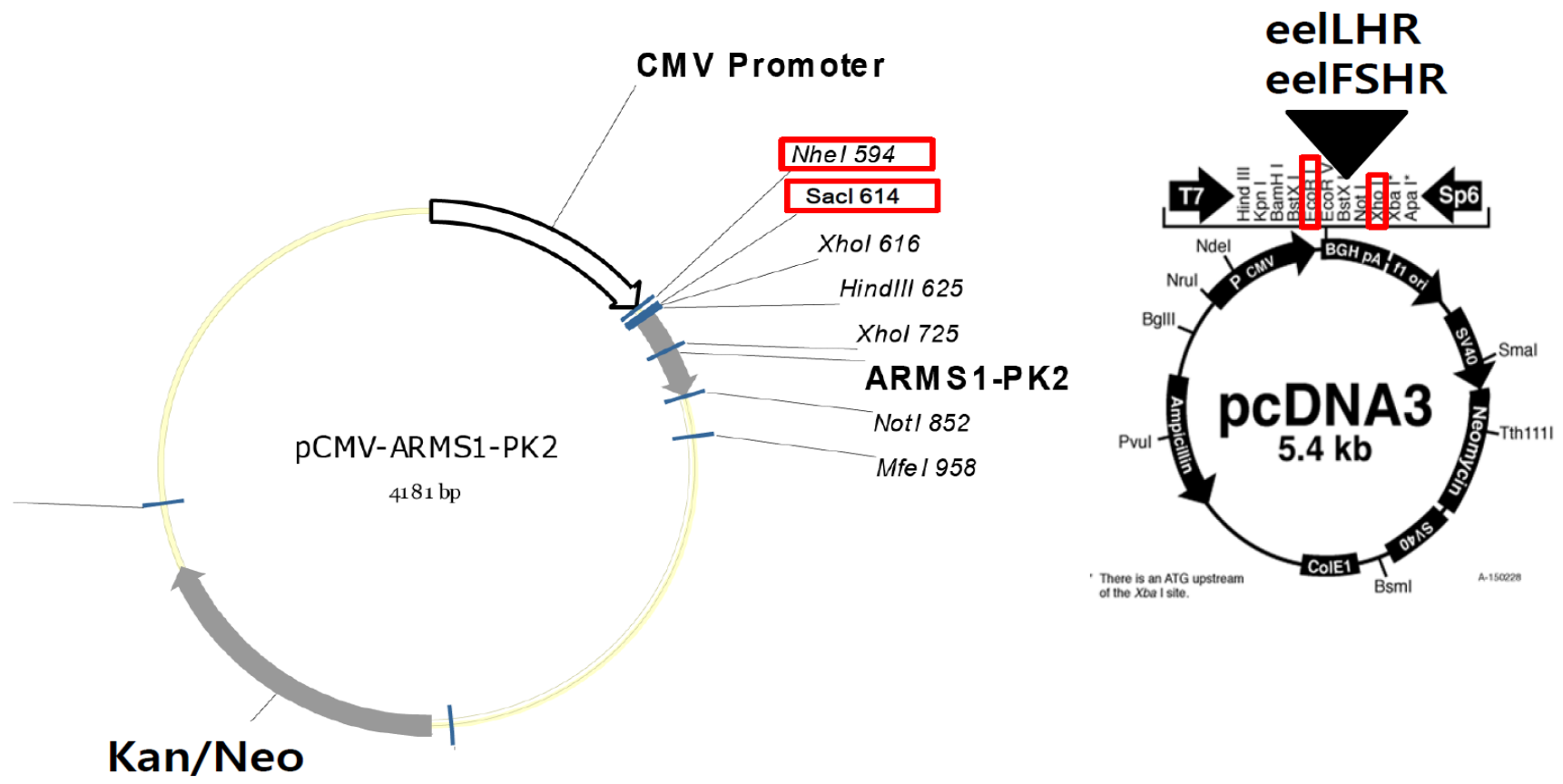

Fig. 2. Cloning of eelLHR and eelFSHR into the mammalian expressing vector. The cDNAs of eelLHR and eelFSHR were ligated into the pCMV-ARMS1-PK2 (NheI-SacI site) and pcDNA3 (EcoRI-XhoI site) mammalian expressing vectors. eelLHR, eel luteinizing hormone receptor; eelFSHR, eel follicle stimulating hormone receptor.

the stable cell lines, transfected cells were seeded at 500 and 1000 cells per $100 \mathrm{~mm}$ culture dish at 24-48 h after transfection. The cells were cultured in AssayComplete medium containing G418 for 2-3 weeks to select for the cells expressing eelFSHR. Approximately 20 clones were recovered and cultured in a 24 well-plate. The grown cells were transferred to 6 -well plates and $25 \mathrm{~cm}^{2}$ culture flasks. Finally, 5 cell clone lines were isolated and stocked, according to a previously reported method (Lee et al., 2017).

6. Evaluation of cAMP level by homogenous timeresolved foster resonance energy transfer (HTRF)

cAMP accumulation in $\mathrm{CHO}$ cells and PathHunter CHOK1 EA-Parental cells was measured using cAMP Dynamics 2 competitive immunoassay kits (Cisbio Bioassays), as described previously (Lee et al., 2017). Briefly, the cAMP assay uses a cryptate-conjugated anti-cAMP monoclonal antibody and d2-labeled cAMP. The transfected eelLHR and eelFSHR cells were plated at 10,000 cells per well into 384-well plates. Five microliters of compounds in medium buffer were added to each well; then, cAMP-d2 $(5 \mu \mathrm{L})$ and anti-cAMP-cryptate ( $5 \mu \mathrm{L})$ were added to each well. Next, the plate was read on a compatible HTRF reader. Results were calculated from the $665 \mathrm{~nm} / 620 \mathrm{~nm}$ absorption ratio and expressed as Delta F \% (cAMP inhibition). The concentration of the standard samples prepared was in the range of 0.17-712 $\mathrm{nM}$ (final concentration of cAMP per well).

\section{Delta $\mathrm{F} \%=$}

(Standard or sample ratio - sample negative $) \times 100$

/ ratio negative

The cAMP concentration for Delta F\% value was calculated by GraphPad Prism.

\section{Data analysis}

Dose-response curves were fitted to a nonlinear regression variable slope equation using GraFit 5.0 (Erithacus Software Limited, Surrey, UK) and GraphPad Prism 6.0 (GraphPad Software, Inc, La Jolla, CA, USA). Curves fitted in a single experiment were normalized to the background 
signaling measured in mock-transfected cells $(0 \%)$. The sum of each curve was calculated from at least three independent experiments.

\section{RESULTS}

1. Production and quantification of rec-eCG $\beta / \alpha$ in CHO-S cells

After transfecting eCG $\beta / \alpha$ vectors into CHO-S cells, the rec-eCG secreted into the serum-free medium was isolated, concentrated, and quantified using ELISA. The quantity of rec-eCG secreted was $200 \mathrm{mIU} / \mathrm{mL}$. The molecular weight of the rec-eCG $\beta / \alpha$ protein was found to be approximately 40-45 kDa (data not shown), which was consistent with that reported in previous studies (Jeoung et al., 2010; Lee et al., 2017).

\section{Isolation of $\mathrm{CHO}-\mathrm{K} 1$ cell lines expressing eelLH/ CGR and CHO-S cell lines expressing eelFSHR}

The mammalian expression vectors for eelLH/CGR were transfected into CHO-K1 cells.

The CHO-K1 cells transfected with eelLH/CGR cDNA were counted and then the cells $(10,000)$ were plated into 383-well plates. PathHunter CHO-K1 cells transfected with eelFSHR cDNA were isolated by G418 treatment. Finally, 10 clone cells were isolated, and the responsiveness of eelFSH receptor was analyzed by agonist treatment. The cAMP level was determined to evaluate the response induced by agonist stimulation.

\section{Biological activity in $\mathrm{CHO}$ cells expressing tran-} sient eelLH/CGR

The effect on cAMP stimulation in CHO-K1 cell lines expressing eelLH/CGR genes was determined to evaluate the activity of rec-eCG $\beta / \alpha$ and native eCG. Receptor-expressing cells were incubated with various concentrations $(0.085-1,500 \mathrm{ng} / \mathrm{mL})$ of ligand. As shown in Fig. 3, Delta $\mathrm{F} \%$ for rec-eCG $\beta / \alpha(\mathrm{B})$ and native eCG (C) gradually de- creased in a dose-dependent manner as compared to the standard curve (0.17-712 nM) (A). Here, the cAMP production, expressed as Delta $\mathrm{F} \%$, was inhibited by activation of the transfected eelLH/CGR. Next, these data were calculated by cAMP concentration (nM) as shown in Fig. 3. The cAMP concentration increased in proportion to the concentration of rec-eCG $\beta / \alpha$ and native eCG. The $\mathrm{EC}_{50}$ values of rec-eCG $\beta / \alpha$ and native eCG were 172.4 and 786.6 $\mathrm{ng} / \mathrm{mL}$, respectively(Table 1 ). The activity was higher 4.5 times for rec-eCG $\beta / \alpha$. Thus, the data suggest that rec-eCG $\beta /$ $\alpha$ and native eCG bound to eelLH/CGR and stimu-lated the receptors.

\section{Biological activity in PathHunter-EA Parental cells} stably expressing eeIFSHR

First, eelFSHR plasmids were transfected into PathHunterEA Parental cells expressing $\beta$-arrestin. Stable clones were selected by G418 treatment. Five clones of 10 positive clones were subjected to cAMP analysis by rec-eelFSH $\beta / \alpha$ treatment. Next, we established the responsive cell lines for rec-eelFSH $\beta / \alpha$. As shown in Fig. 4, cAMP response to rec-eCG $\beta / \alpha$ and native eCG was analyzed. Delta F\% gradually decreased a dose-dependent manner compared to the standard curve (0.17-712 nM) (Fig. 4A). However, we did not find any dose-dependent response $(0.085-1,500 \mathrm{ng} / \mathrm{mL})$ for rec-eCG $\beta / \alpha$ and native eCG treatment (Fig. 4 B,C). The curve was flat as shown in Fig. 4B,C. This suggests that eelFSHR does not bind with eCG. Thus, there were no changes in cAMP concentration in eelFSHR-expressing cells in response to eCG binding. eCG is, therefore, not suitable for promoting eel ovulation and maturation.

\section{DISCUSSIONS}

The results of the present study showed that rec-eCG $\beta / \alpha$ and native eCG induced signal transduction by eelLH/ CGR in CHO-K1 cell lines that expressed these receptors in a time- and concentration-dependent manner. However, 
A) Standard

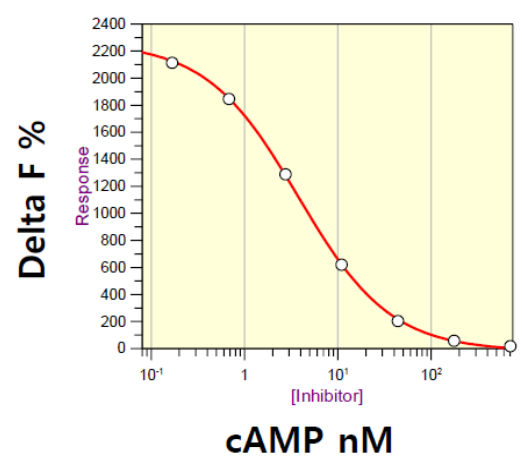

cAMP nM
B) eeILHR
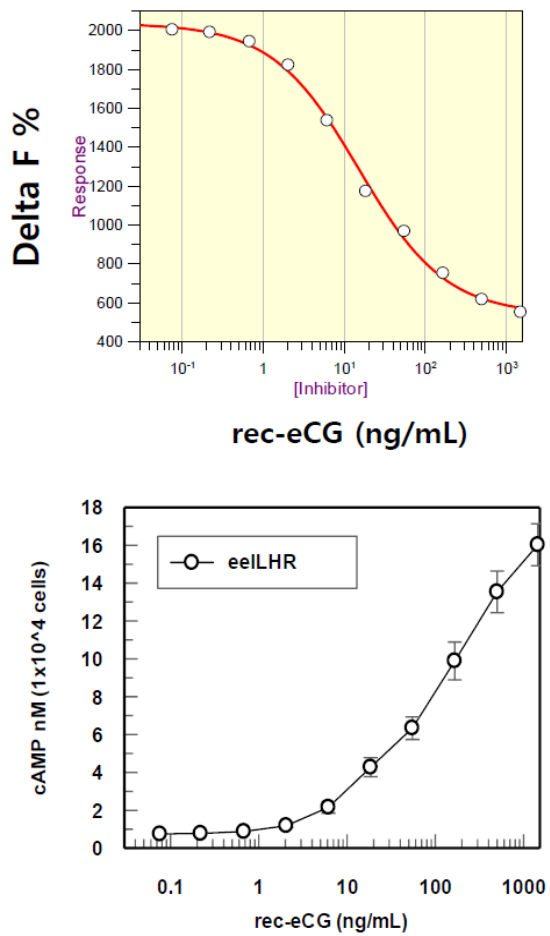

C) eeILHR
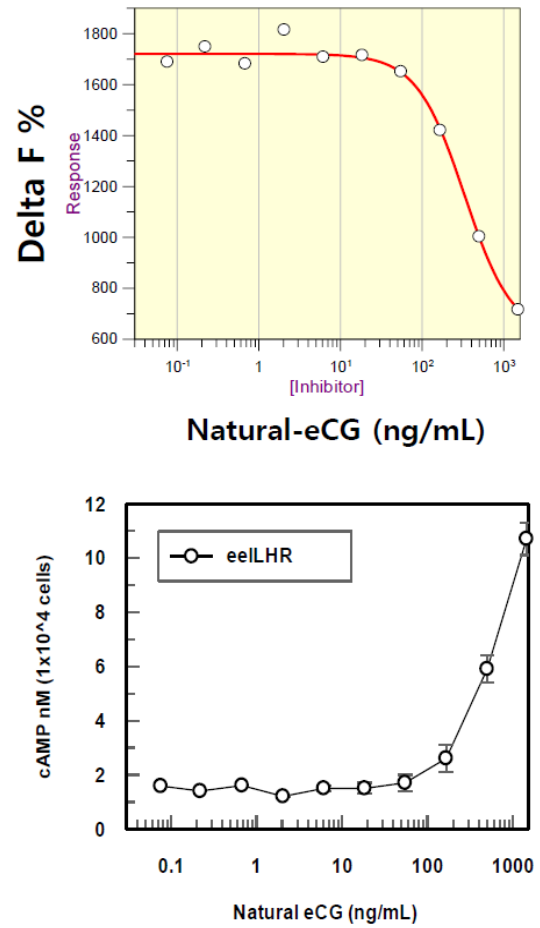

Fig. 3. Dose-dependent inhibition and increase in cAMP accumulation induced by rec-eCG $\beta / \alpha$ and native eCG in cells transiently expressing eeILH/CGR. CHO-K1 EA Parental cells were transfected with eelLH/CGR. The transfection method is described in the Materials and Methods section. The transfected culture media were replaced with new $\mathrm{CHO}$ growth medium $24 \mathrm{~h}$ after transfection. Cells were subjected to cAMP analysis $48-72 \mathrm{~h}$ after transfection. The standard samples were prepared across a concentration range of $0.17-712 \mathrm{nM}$. The plate was incubated for 30 min after adding rec-eCG $\beta / \alpha(0-1,500 \mathrm{ng} / \mathrm{mL})$. cAMP $\mathrm{d} 2$ and anti cAMP-cryptate were added and incubated at RT for $1 \mathrm{~h}$. Inhibition of cAMP accumulation was shown by Delta F\%, and the cAMP concentration was calculated by GraphPad Prism. A) Standard curve, B) and C) Delta F\% value was shown by inhibition of cAMP responsiveness (GraFit), cAMP nM $\left(1 \times 10^{4}\right.$ cells) calculated by GraphPad Prism. cAMP, cyclic adenosine monophosphate; rec-eCG, recombinant equine chorionic gonadotropin; $\mathrm{eCG}$, equine chorionic gonadotropin; RT, reverse transcription.

the eelFSHR-expressing cells did not exhibit any response to rec-eCG $\beta / \alpha$ and native eCG.

In previous studies, we reported rec-eCG production in CHO-K1 cells (Min et al., 2004; Park et al., 2009, 2010; Jeoung et al., 2010). However, the specific glycosylation site is very important for the secretion of rec-eCG in CHOK1 cells (Min et al., 2004). We also stably transfected CHO-K1 cells with rFSHR and rLH/CGR cDNA. In previous studies, rec-eCG $\beta / \alpha$ was shown to activate both rFSHR and rLH/CGR in non-equids, but only LH-like activity was observed in equid species (Park et al., 2009;
2010). eCG does not bind to FSH receptors in equine follicles (Guillou \& Combarnous, 1983; Murphy \& Martinuk, 1991) or testis (Moore \& Ward, 1980), suggesting that eCG is primarily an LH-like hormone in horses. However, eCG binds to donkey FSH receptors with an affinity similar to its affinity of binding to donkey LH receptors (Guillou \& Combarnous, 1983; Murphy \& Martinuk, 1991), a finding that has been interpreted to indicate that eCG may have FSH activity in donkey (Stewart \& Allen, 1981).

One of the intriguing properties of eCG is its dual activity in species other than the horse. The analysis of the bio- 
Signal Transduction of eelLHR and eeIFSHR

Table 1. Bioactivity of the rec-eCG $\beta / \alpha$ and native eCG in CHO-K1 cells expressing eelLH/CGR

\begin{tabular}{cccc}
\hline \hline $\begin{array}{c}\text { eCG type } \\
\text { CHO-K1 cells } \\
\text { (transient) }\end{array}$ & $\begin{array}{c}\text { Basal } \\
\left(\mathrm{nM} / 10^{4} \text { cells }\right)\end{array}$ & $\begin{array}{c}\mathrm{EC}_{50} \\
(\mathrm{ng} / \mathrm{mL})\end{array}$ & $\begin{array}{c}\text { Rmax } \\
\left(\mathrm{nM} / 10^{4} \text { cells }\right)\end{array}$ \\
\cline { 2 - 4 } Rec-eCG $\beta / \alpha$ & 0.53 & $172.4(118$ to 251$)$ & 19.6 \\
Native eCG & 1.54 & $786.6(527$ to 1,174$)$ & 14.54 \\
\hline
\end{tabular}

Values are the means of triplicate experiments. The $\mathrm{EC}_{50}$ values used to determine the potency were obtained from the concentration-response curves for the in vitro bioassays.

rec-eCG $\beta / \alpha$, recombinant equine chorionic gonadotropin ; eCG, equine chorionic gonadotropin; cAMP, cyclic adenosine monophosphate; EC, effective concentration.

A) Standard

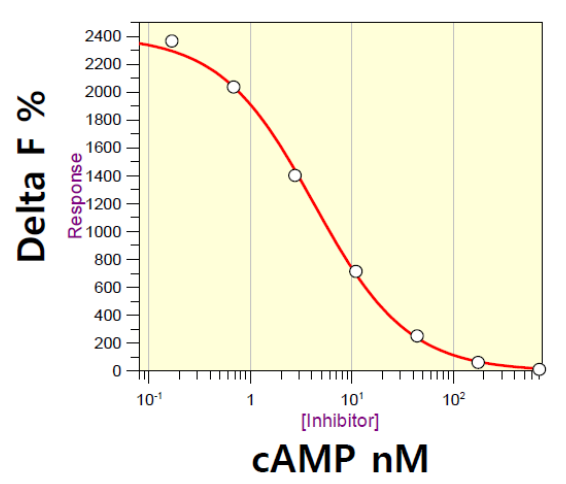

B) eelFSHR

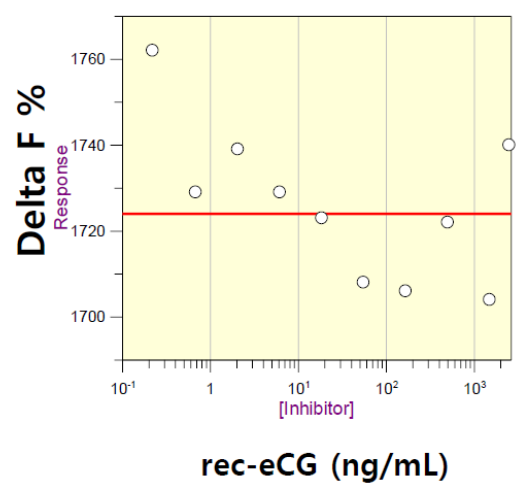

C) eeIFSHR

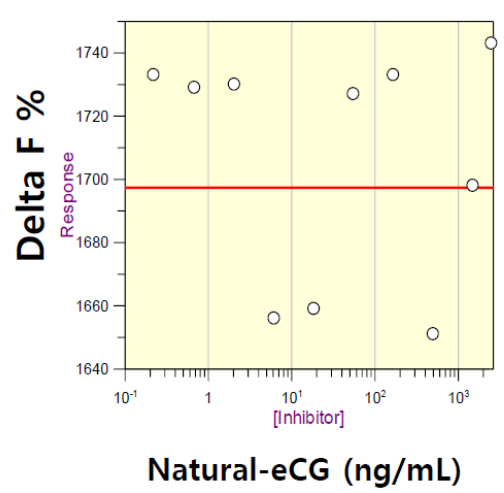

Fig. 4. Dose-dependent inhibition and increase in cAMP accumulation induced by a rec-eCG $\beta / \alpha$ and native eCG in stably cells expressing eelFSHR. PathHunter CHO-K1 EA Parental cells were transfected with eelFSHR. The stably expressing cells were seeded at 10,000 cells per well into 384-well plates. The standard samples were prepared across a concentration range of 0.17-712 $\mathrm{nM}$. The plate was incubated for $30 \mathrm{~min}$ at RT after adding rec-eCG $\beta / \alpha$ (0-1,500 ng/mL). A) Standard curve, B) and C) Delta F\% value was shown by inhibition of cAMP responsiveness (GraFit). cAMP, cyclic adenosine monophosphate; rec-eCG $\beta / \alpha$, recombinant equine chorionic gonadotropin ; eCG, equine chorionic gonadotropin; eelFSHR, eel follicle stimulating hormone receptor; RT, reverse transcription.

logical activity of eCG has been further complicated by the use of a variety of standards, including ovine, bovine, human and equine gonadotropins, all with different inherent activity (Aggarwal \& Papkoff, 1980; Murphy \& Martinuk, 1991). Our previous results agree with those of reports that state that rec-eCG exhibits biological activity (Min et al., 1996, 2004; Park et al., 2009, 2010). These results indicated that rec-eCG produced from mammalian cells could be useful for improving the development of dominant and pre-ovulation follicles in non-equids.

Labeling and pulse-chase experiments showed that the secretion of the eCG $\beta$-subunit from $\mathrm{CHO}-\mathrm{K} 1$ cells was inefficient (medium recovery of 16-25\%) and slow $\left(t_{1 / 2}>6.5 \mathrm{~h}\right)$. This secretion of the eCG $\beta$-subunit resembled that of the hLH $\beta$-subunit, rather than that of the hCG $\beta$ subunit (Cohen et al., 2015). Previous studies showed that 
rec-eCG $\beta / \alpha$ can be expressed in the baculovirus-Sf9 insect cell system (Legardinier et al., 2008). Heterodimeric receCG exhibited the same thermal stability as native pituitary $\mathrm{LH}$, and rec-eCG advantages over the single-chain eCG included higher secretion, higher in vitro bioactivity, and lower risk of immunogenicity (Legardinier et al., 2008).

In the present study, rec-eCG $\beta / \alpha$ showed higher activity than native eCG. In a previous study, rec-eCG produced from Mimic insect cells showed mammalian-like nonsialyl complex-type N-glycosylation (Legardinier et al., 2005a,b). Native eCG contains complex-type $\mathrm{N}$-glycans with both Sian2,3Gal and Sia 2,6Gal at the ends. We suggest that the differences in structure between rec-eCG $\beta / \alpha$ and native eCG may account for the different results in the quantitative analysis by ELISA. We also suggested that the degradation rate of the mutant rec-eCG, which was deglycosylated at $\mathrm{Asn}^{56}$ of the $\alpha$-subunit, was not increased because of the conformation of the hormone-receptor complex (Park et al., 2017).

Based on the data presented, rec-eCG $\beta / \alpha$ and native eCG did not increase cAMP responsiveness in the cells expressing eelFSHR. Thus, we suggest that the dual activity of eCG differs between mammals and fish. Although eCG did not elicit any activity in the cells expressing eelFSHR, eCG increased the biological activity in the cells expressing eelLH/CHR. Therefore, we suggest that receCG and native eCG are not suitable for the maturation and ovulation of female eels. We recommend that rec-eCG and native eCG can be used for sexual-maturation in female and male eels because eCG bound to the eelLH/CGR and increased the cAMP response. rec-eelFSH appears to exert biological activity in cells expressing the eFSHR gene (in preparation). Thus, we suggest that the rec-eel FSH hormone binds to the eFSHR, and eFSH may bind to eelFSHR.

Therefore, we conclude that rec-eCG and native eCG do not stimulate the cells expressing eelFSHR. The dual FSH- and LH-like activity of eCG is differ between mammalian and fish species. Further studies are required to conclusively determine whether the dual activity of eCG is indeed responsible for the uncoupling of eFSHR and eLH/CGR.

\section{ACKNOWLEDGEMENTS}

This work was financially supported by Korean Research Foundation Program (2018R1A2B6007794), Republic of Korea.

\section{REFERENCES}

Aggarwal BB, Papkoff H (1980) Effects of histidine modification on the biological and immunological activities of equine chorionic gonadotropin. Arch Biochem Biophys 202:121-125.

Chopineau M, Martinat N, Galet C, Guillou F, Combarnous Y (2001) $\beta$-Subunit 102-104 residues are crucial to confer FSH activity to equine LH/CG but are not sufficient to confer FSH activity to human CG. J Endocrinol 169:55-63.

Cohen L, Bousfield GR, Ben-Menahem D (2015) The recombinant equine LH $\beta$ subunit combines divergent intracellular traits human LH $\beta$ and CG $\beta$ subunits. Theriogenology 83:1469-1476.

Galet C, Guillou F, Foulon-Gauze F, Combarnous Y, Chopineau M (2009) The $\beta 104-109$ sequence is essential for the secretion of correctly folded single-chain $\beta \alpha$ horse LH/CG and for its FSH activity. J Endocrinol 203:167-174.

Guillou F, Combarnous Y (1983) Purification of equine gonadotropins and comparative study of their aciddissociation and receptor-binding specificity. Biochim Biophys Acta 755:229-236.

Jeoung YH, Yoon JT, Min KS (2010) Biological functions of the $\mathrm{COOH}$-terminal amino acids of the $\alpha$-subunit of tethered equine chorionic gonadotropin. Reprod Dev 
Sci 34:47-53.

Kagawa H, Iinuma N, Tanaka H, Ohta H, Okuzawa K (1998) Effects of rearing period in seawater on induced maturation in female Japanese eel Anguilla japonica. Fish Sci 64:77-82.

Kazeto Y, Kohara M, Miura T, Miura C, Yamaguchi S, Trant JM, Adachi S, Yamauchi K (2008) Japanese eel FSH and luteinizing hormone (LH): Production of biologically active recombinant FSH and LH by Drosophila S2 cells and their differential actions on the reproductive biology. Biol Reprod 79:938-946.

Kim DJ, Park CW, Byambaragchaa M, Kim SK, Lee BI, Hwang HK, Myeong JI, Hong SM, Kang MH, Min KS (2016a) Data on the characterization of folliclestimulating hormone monoclonal antibodies and localization in Japanese eel pituitary. Data Brief 8:404-410.

Kim DJ, Park CW, Kim DW, Park HK, Byambaragchaa M, Lee NS, Hong SM, Seo MY, Kang MH, Min KS (2016b) Production and characterization of monoclonal antibodies against recombinant tethered follicle-stimulating hormone from Japanese eel Anguilla japonica. Gem Comp Endocrinol 233:8-15.

Kobayashi M, Hayakawa Y, Park W, Banba A, Yoshizaki G, Kumamaru K, Kagawa H, Nagaya H, Sonh YC (2010) Production of recombinant Japanese eel gonadotropins by baculovirus in silkworm larvae. Gen Comp Endocrionol 167:379-386.

Lee SY, Byambaragchaa M, Kim JS, Seong HK, Kang MH, Min KS (2017) Biochemical characterization of recombination equine chorionic gonadotropin (rec-eCG), using $\mathrm{CHO}$ cells and pathHunter parental cells expressing equine luteinizing hormone/chorionic gonadotropin receptors (eLH/CGR). Life Sci 27:864-872.

Legardinier S, Duonor-Cérutti M, Devauchelle G, Combarnous Y, Cahoreau C (2005a) Biological activities of recombinant equine luteinizing hormone/chorionicgona dotropin (eLH/CG) expressed in Sf9 and Mimic insect cell lines. J Mol Endocrinol 34:47-60.
Legardinier S, Klett D, Poirier JC, Combarnous Y, Cahoreau C (2005b) Mammalian-like nonsialyl complextype N-glycosylation of equine gonadotropins in Mimic $^{\mathrm{TM}}$ insect cells. Glycobiology 15:776-790.

Legardinier S, Poirier JC, Klett D, Combarnous Y, Cahoreau C (2008) Stability and biological activities of heterodimeric and single-chain equine $\mathrm{LH} /$ chorionic gonadotropin variants. J Mol Endocrinol 40:185-198.

Min KS, Hattori N, Aikawa JI, Shiota K, Ogawa T (1996) Site-directed mutagenesis of recombinant equine chorionic gonadotropin/luteinizing hormone: Differential role of oligosaccharides in luteinizing hormone- and follicle-stimulating hormone-like activities. Endocrine 43:585-593.

Min KS, Hiyama T, Seong HH, Hattori N, Tanaka S, Shiota $\mathrm{K}$ (2004) Biological activities of tethered equine chorionic gonadotropin (eCG) and its deglycosylated mutants. J Reprod Dev 50:297-304.

Moore WT, Ward DN (1980) Pregnant mare serum gonadotropin. J Biol Chem 250:6930-6936.

Murphy BD, Martinuk SD (1991) Equine chorionic gonadotropin. Endocr Rev 12:27-44.

Ohta H, Miyake H, Miura C, Kamei H, Aida K, Miura T (2007) Follicle-stimulating hormone induces spermatogenesis mediated by androgen production in Japanese eel, Anguilla japonica. Biol Reprod 77:970-977.

Ohta H, Sato Y, Imaizumi H, Kazeto Y (2017) Changes in milt volume and sperm quality with time after an injection of recombinant Japanese eel luteinizing hormone in male Japanese eels. Aquaculture 479:150-154.

Park JJ, JarGal N, Yoon JT, Min KS (2009) Function of the tethered rec-eCG in rat and equine receptors. Reprod Dev Biol 33:229-236.

Park JJ, JarGal N, Yoon JT, Min KS (2010) $\beta$-subunit 9496 residues of tethered recombinant equine chorionic gonadotropin are important sites luteinizing hormone and follicle stimulating hormone like activities. Reprod Dev Biol 34:33-40. 
Park JJ, Seong HK, Kim JS, Munkhzaya B, Kang MH, Min KS (2017) Internalization of rat FSH and LH/CG receptors by rec-eCG in CHO-K1 cells. Dev Reprod 21:111-120.
Stewart F, Allen WR (1981) Biological functions and receptor binding activities of equine chorionic gonadotrophins. J Reprod Ferti 62:527-536. 